J. Product. \& Dev., 19(2):113 - 122 (2014)

\title{
EFFECT OF CHEMICAL, BIO AND ORGANIC FERTILIZERS ON GROWTH AND YIELD AND BULB QUALITY OF ONION PLANTS GROWN IN ZAWIA REGION, LIBYA
}

\author{
E. H. Abou El-Salehein*; N. A. Kushlaf** and Ahlam, Rashed, F. \\ Rashed** \\ * Faculty of Veterinary and Agricultural Science, Plant Prod. Department, \\ Zawia University, Zawia, Libya. \\ ** Faculty of Science, Botany Department, Zawia University, Zawia, Libya.
}

\begin{abstract}
:
This investigation was conducted during the two successive winter seasons of 2011/2012 and 2012/2013 at Private Farm, ZawiaZone, Libya, to study the performance of onion cv. Early Texas Grano SR 502 to chemical fertilizer of hakaphos, biofertilizer of nitrobein and organic fertilizerof sheep manure and some its combined effect on growth, bulb yield and quality of onion.Application of the triple treatment of hakaphos + sheep manure + nitrobein caused significantly increases on plant growth characters, bulb yield and its quality (the nutritive value of bulb) in both growing seasons, followed by Hakaphos with nitrobein and /or sheep manure treatments in most cases of studied characters.

Conclusively, it can be recommended from the obtained results that treating of onion plants with the triple treatment of Hakaphos, nitrobein and sheep manure, followed by mixture of Hakaphes and nitrobein or sheep manure enhancing plant growth characters, bulb yield and its components, as well as, the nutritive value of bulbs, in most two growing seasons.
\end{abstract}

Key words: Onion, Hakaphos, nitrobein, sheep manure yield, marketable, culls.

\section{INTRODUCTION}

Onion (Allium cepa L.) is one of the important vegetable crops in Libya. Fertilization is a major factor affecting onion growth, chemical composition and yield. Recently, has been directed to use organic and biofertilizers as a substitute or to minimize mineral fertilizer to decrease the pollution of the agricultural environment and produce healthy food for human. biofertilizers such as nitrobein plays a fundamental role on fixation of air nitrogen, which has microorganisms azotobactar and Azosperillum, as well as, imported plant growth , chemical composition and yield of onion 
plant (Barakat et al., 2004; El-Shaikh, 2005; Ahmed, 2009 and Fekry and Abou El-Salehein, 2010).

Growth of most vegetable crops including onion was improved by applying different organic fertilizers, such as sheep manure. It is serve as a soil amendment by adding organs matter and good source of nutrient and contains both macro and micro-essential nutrients for plant growth, dry matter, bulb yield and its quality of onion plants (Mahmond, 2006; Yassen and Khalid, 2009; Fekry and Abou El-Salehein, 2010 and Lee, 2010).

Several investigators reported that using complete chemical fertilizers, such as Hakaphos, are considered promoting plant growth and increasing yield and its quality of onion plant (Ahmed, 2009; Fekry, 2009 and Ibraheim, 2010).

Therefore, this experiment was carried out to study the response of onion plant to organic manure (cheep manure ) biofertilizer (nitrobein ) and complete fertilizer (Hakaphos ) either in a single form or in combination on growth, yield and bulb quality.

\section{MATERIALS AND METHODS}

The experiment of this study was carried out at Private Farm, at Zawia Zone, Libya during the two successive winter seasons of 2011/2012 and 2012/2013 to study the effete of organic manure (Sheep manure 1, bio fertilizer (Nitrobein) and complete fertilizer (Hakaphos) on vegetative growth characters, yield and its components and nutritive value of onion bulbs cv, Early Texas Grano SR502 under sandy soil conditions. The soil chemical constituents are presented in Table 1.

Table 1. Soil chemical analysis of the experimental field.

\begin{tabular}{|l|c|}
\hline Character & Values \\
\hline Available nitrogen & $87 \mathrm{ppm}$ \\
Available potassium & $114 \mathrm{ppm}$ \\
$\mathrm{pH}$ & 7.5 \\
Organic matter (DM) & $0.07 \%$ \\
CEC ( Cation exchangeable capacity ) & $18.0(\mathrm{meg} / 100 \mathrm{~g}$. Soil) \\
\hline
\end{tabular}

Sheep manure was applied at the rate of 10 ton /hectare in one dose during soil preparation and the analysis of sheep manure are shown in Table 2.

The soil was prepared and nitroben inoculated onion seedlings, which were shown on one side of the rows. Sprinkler irrigation system was used. Seeds were shown on $13^{\text {th }}$ and $11^{\text {th }}$ of October in 2011 and 2012 seasons, respectively and seedlings were transplanted after 75 days from sowing. 
Table 2. Chemical analysis of the used Sheep manure.

\begin{tabular}{|l|c|}
\hline Chemical contents and characters & Values \\
\hline $\mathrm{pH}$ & 6.7 \\
Electric conductivity (EC) & 3.6 \\
Total organic carbon & 26.6 \\
C/N ratio & $1: 33.4$ \\
Total nitrogen (\%) & 0.85 \\
Total potassium (\%) & 0.31 \\
Total phosphor (\%) & 0.43 \\
Ach (\%) & 6.11 \\
Moisture (\%) & 54.0 \\
\hline
\end{tabular}
follows:

This experiment included eight treatments at both growing seasons as

1. Control (without any addition ).

2. Hakaphos fertilizer $\left(1 \mathrm{Kg}\right.$ hectare $\left.^{-1}\right)$.

3. Nitrobein , at $400 \mathrm{~g}$. hetare ${ }^{-1}$, as a source of nitrogen fixing bacteria, i.e. Azotobacterspp + Azospirillium spp.

4. Sheep manure, at 10 ton hectare ${ }^{-1}$

5. Hakaphos + nitrobein.

6. Hakaphos + sheep manure.

7. Nitrobein + sheep manure.

8. Hakaphos + nitrobein + sheep manure.

The treatments of Hakaphos fertilization were added to the plants as foliar at two times, 30 and 45 days after transplanting. The Hakaphos producted from Company Iberia S.L Division Compo Expert C, Joan of Austria 39-47, 08005 Barcelona, S, oain. The constituents of Hakaphos are shown in Table 3.

Table 3. The constituents of Hakaphos fertilizer

\begin{tabular}{|l|c|}
\hline Contents & Percentage (\%) \\
\hline Total nitrogen $(\mathrm{N})$ & 15 \\
\hline Ammonia & 4.8 \\
\hline Nitric acids & 10.2 \\
\hline Phosphoric Anhydride $\left(\mathrm{P}_{2} \mathrm{O}_{5}\right)$ & 5 \\
\hline Potassium Oxide & 30 \\
\hline Sulfuric Anhydride & 9.0 \\
\hline Boron $(\mathrm{B})+$ & 0.01 \\
\hline Cupper $(\mathrm{Cu})+$ & 0.02 \\
\hline Iron $(\mathrm{Fe})+$ & 0.05 \\
\hline Manganese $(\mathrm{Mn})+$ & 0.05 \\
\hline Molybdenum $(\mathrm{Mo})+$ & 0.001 \\
\hline Zinc $(\mathrm{Zn})+$ & 0.001 \\
\hline
\end{tabular}


The area of each of experimental unit was, $5.4 \mathrm{~m}^{2}$, it contained three ridges with $3 \mathrm{~m}$ length and $60 \mathrm{~cm}$ in width. The distance between plants was $15 \mathrm{~cm}$ on one side of the row. One ridge was left between each two plots as a guard. Sprinkler irrigation system was used. The treatment were arranged in a randomized complete block design with three replicates.

\section{Data recorded:}

1.Plant growth parameters: A random sample of five plants from each experimental unit was randomly taken at 100 days after transplanting in both growing seasons of the study and the following data were recorded:

a.Morphological characters: Plant height $(\mathrm{cm})$, number of blades / plant, neck length and bulb diameter $(\mathrm{cm})$

b. Fresh and dry weight: The different parts of onion plant, i.e.blades and bulbs were dried at $70^{\circ} \mathrm{C}$ till constant of these parts and total dry weight /plant (g) were recorded.

2.Yield and its components: Onion plants were harvested when $75 \%$ of plant tops were down. After curing, the following data on representative sample of five bulbs were recorded, average bulb fresh weight (g), marketable, culls and total bulb yield in all bulbs of plots were determined and then calculated to hectares (ton).

3.Nutritional value of bulbs: $\mathrm{N}, \mathrm{P}$ and $\mathrm{K}$ contents: At harvest time, five bulbs were randomly taken from each treatment and oven dried at $70^{\circ} \mathrm{C}$ till constant weight and the contents of nitrogen, phosphorus and potassium were finely ground and digested according to the methods described by Bremner and Mulvancy (1982), Olsen and Sommers (1982) and Jakson (1970), respectively.

\section{Statistical analysis:}

Collected data were subjected to statistical analysis of variance according snedecor and Cochran (1980) and treatments mean were compared using least significant difference (LSD) at the level of $5 \%$.

\section{RESULTS AND DISCUSSION :}

\section{Plant growth characters:}

\section{A. Vegetative growth:}

Data presented in Table (4) clearly show that supplying onion plants with the tripls treatment of Hakaphos, nitrobein and sheep manure led to significant differences in growth features of onion plants, i.e. plant height, number of blades/ plant and diameter of bulb in both growing seasons, but in neck length in the second season only, followed by the treatments of Hakaphos + nitrobein and Hakaphos + sheep manure, respectively in most 
causes. On the other hand, the lowest values of vegetative growth characters were obtained by the control treatment (Table 4).

As the favorable effect of Hakaphos in increasing plants growth, it might be due to the macro and microelements which contains of this compound that improved the growth characters, as well as, the essential nutrients inhanced the biosynthesis in plant and turn in increasing the plant growth (Ahmed, 2009 and Fekry and Abou El-Salehein, 2010).

Obtained by nitrogen, it may be due to the role of it release of the fixing nitrogen (Which contains on Azotobacter and Azospirillum bacterial), mobilizing of certain macro and micro nutrients to a form available for plant a absorption and secretion a set of growth promoting substances (Saber and Gomma, 1993).

Moroever, as for the increases in plant growth obtained by sheep manure, it might be due to the improvement of physical and chemical properties of soil (Karam, 2005), Which affected soil fertility and play an important role in nutrients availability and uptake .

These favorable conditions allow routs system and plant to grow better and more assimilations would be stored (Fawzyet al., 2007).

From the foregoing results, it could be concluded that application of triple treatment with chemical fertilizer of Hakaphos, biofertilizer with nitrogen and organic manure with sheep manure expected a marked effect on vegetative growth of onion plants.

The obtained results followed the same results of that reported by Ahmed (2009), Fekry (2009) and Ibraheim (2010) on chemical fertilizers; Barakat et al., (2004), El-Shaikkh (2005) and Fekry and Abou El- Salehein (2010) on biofertilizers and Mahmoud (2006), Yassen and Khalid (2009) and Lee (2010) on organic manure.

\section{B-Fresh and dry weight of plants:}

Data tabulated in Table (5) revealed that all used treatments had a marked effect on fresh weight of both blades too and total dry weight of onion plants. In general, application of the triple treatment which containing on Hakaphos, nitrogen and sheep manure, followed by the treatments of Hakaphos + nitrobein and finely Hakaphos+ sheep manure, respectively, which mostly archived the highest values of fresh and dry weight of onion plants.

Of the triple treatment might be attributed to the increase in photosynthetic capacity to which the number of blades per plant could be reliable index as application of Hakaphos fertilizer, nitrogen biofertilizer and sheep manure. Moreover, application of these mixtures promoting the 
physiological, biochemical and metabolic processes in which in turn increased the accumulation of the dry matter content in the plant.

The obtained results are in harmony with those reported by Barakat et al., (2004), Fekry and Abou El- Salehein(2010) and Lee (2010).

\section{Bulb yield and its components:}

It is clearly evident from data in Table (6) that application of all used treatments had a significantly increased in bulb yield and its components compared with the control treatment in both growing seasons the triple treatment of application with Hakaphos, nitrobein and sheep manure , being the most effective on bulb yield and its components of onion, i.e. average weight of bulb, marketable bulb yield/ hectare and total bulb yield hectare and total bulb yield /hectare.

On the other hand, the lowest values of culls bulb yield /hectare were obtained by the same treatment of triple application. Meanwhile, the lowest values of average weight of bulb, marketable bulb yield/hectare and total bulb yield /hectare and highest values of culls bulb yield /hectare were obtained by treatment of control.

Increments of onion yield with the triple treatment may be attributed to the vigorous vegetative plant growth as shown in Tables (4 and 5), and to the improving effect of hakaphos, which contained on macro and micro. Elements that important for the activity of photosynthesis and the accumulation of metabolites in reproductive organs and this reflects on the bulb and consequently on the bulb dry matter content, weight of bulb and consequently on yield per hectare. As well as, the another of both nitrobein and sheep manure were completed the role of Hakaphos for increasing the bulb yield and its components. These results are in confirming with those reported by Fekry(2009) and Ibrahim (2010) on chemical fertilizers, ElShaikh (2005) and Fekry and Abou El-Selehein (2010) on biofertilizers and Mahmoud (2006) and Lee (2010) on organic fertilizers.

\section{The Nutritional values of bulbs (bulb quality):}

Data recorded in Table (7) indicate that N, P and $\mathrm{K}$ contents in onion bulbs exhibited the maximum values in case of treating onion plants with the triple treatment of Hakaphos+ nitrobein+ sheep manure followed in decending order by Hakaphos+ nitrobein and Hakaphos+ sheep manure, respectively.

The favorable effect of Hakaphos on the chemical composition of bulb night be attributed to the contents of $\mathrm{N}, \mathrm{P}, \mathrm{K}$ in Hakaphos, release these nutrients with nitroben which containing on Azotobacter and Azospirillum, bactcria might be attributed to the promoting effect of its on the consequently increased its content in root zone which led to the improvement 
of nitrogen uptake (SubbaRao, 1993). These results are in agreement with those reported by Fekry (2009), Fekry and Abou El-Salehein (2010) and Lee (2010) on chemical fertilizer, biofertilizer and organic manure, respectively.

Conclusively, it can be recommended from the obtained results that treating of onion plants with the triple treatment of Hakaphos, nitrobein and sheep manure, followed by mixture of Hakaphes and nitrobein or sheep manure enhancing plant growth characters, bulb yield and its components, as well as, the nutritive value of bulbs, in most two growing seasons.

\section{REFERENCES:}

Ahmed, M.E.M.(2009). Effect of some bio and mineral fertilization levels on the growth, productivity and storability of onion. Annals of Agricultural Science, Cairo, Egypt, 54(2): 427-436.

Barakat, M.A.,H.A.Elkhatib , S. M.Gabr, and E.A. Bedawy (2004). Plant growth characters of field grown onion (Allium cepa L.) as affected by nitrogen application and biofertilizers inoculation. J.Agric.Sci., Mansoura Univ., Egypt, 29(1):345-356.

Bremner, J.M. and C.S. Mulvancy (1982). Total Nitrogen, In: pags, A. I., R. H. Miller and Keeney, D.R and (Eds). Methods of soil Analysis. Part 2. J. Amer. Soc. Agron. Madison, W.I. USA, pp:595-624.

El-Shaikh, K.A.A (2005). Growth and yield of onion as affected by biofertilization, application of nitrogen and phosphorus fertilizers under south valley conditions. Assiut J. Agric. Sci., Egypt,36 (1):37-50.

Fawzy, Z.F., A.M.El-Bassiony and S.A. Saleh (2007). Effect of chemical fertilizer, poultry manure and biofertilizer on growth, yield and chemical contents of tomato plants. J. Agric. Sci., Mansoura Univ, Egypt, 32(8):6583-6594.

Fekry, Wafaa, A. (2009). Effect of NPK and some biofertilizers on growth, yield and quality of garlic plants. J. Product.\& Dev., Egypt, 14 (3): 655-671.

Fekry, Wafaa, A. and E. H. AbouEl- Salehein (2010). Influence of different sources of fertilizers and yeast on growth, chemical composition, yield and its quality of onion plants. J. Product \& Dev., 15(3) : 403-423.

Ibraheim, Sabreen, K.A.(2010). Effect of different fertilizers on yield and nutritional value of onion under sandy soil conditions. Ph.D. Thesis, Faculty of Agriculture, Zagazig University, Egypt, pp133.

Jackson, M.I.(1970). Soil Chemical Analysis. Prentic Hall, Englewood Ceifts, N. J.

Karam, S.S. (2005). Physiological studies on some onion cultivars. Ph.D.Thesis, Faculty of Agriculture, Zagazig University, Benha Branch, Moshtohor, Egypt, pp.113. 
Lee, J. (2010). Effect of application methods of organic fertilizer on growth, soil chemical properties and microbial densities in organic bulb onion production. Sciential Horticulturae, 124 (3):299-305.

Mahmoud, M.R. (2006). Effect of some organic and inorganic nitrogen fertilizers on onion plants grown on a sandy calcareous soil. Assiut J. Agric. Sci., Egypt, 37(1): 147-159.

Olsen, S.R. and L.E. Sommers (1982). Phosphorous in: page, A.L., Miller, R.H and Keeney (Eds), D.R. Methods of soil Analysis, Part 2. Amer. Soc. Agron. Madison, W.I.USA, pp.403-430.

Saber, M.S. and A.M.K.Gomma(1993). Associative action multi strain biofertilizer on tomato plants grown in a newly reclaimed soil. International Symposium on Biological Nitrogen Fixation With Non Legumes, Sept., 6-10, Ismailia, Egypt, 493-497.

Snedecor, G.W. and W.G.Cochran (1980). Statistical Methods. The Iowa State Univ., Press, Amer., $7^{\text {th }}$ ed.

Subba Rao, N.S.(1993). Biofertilizers in Agriculture. $3^{\text {ed }}$ (Eds), Oxford \& IBH Publishing Co. Ltd, New Delhi, Bombay, Calcutta, pp.219.

Yassen, A.A and K.A. Khalid, (2009). Influence of organic fertilizers on the yield, essential oil and mineral content of onion. Int. Agrophysics, 23:183-188.

\section{تأثثير الأسمدة الكيماوية، والحيوية والعضوية علي النمو ، المحصول وجودة أبصال نباتات البصل النامية في منطقة الزاوية بليبية النيا.}

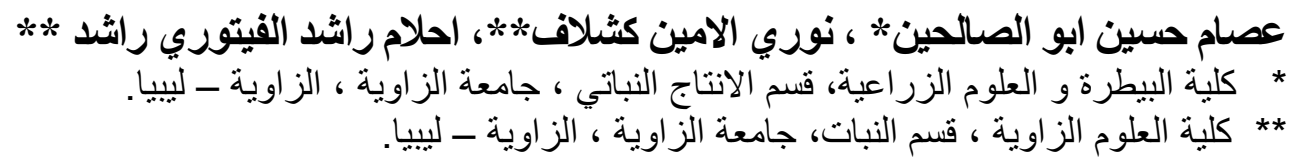

